\title{
A Cancer Specific Cell-Penetrating Peptide, BR2, for the Efficient Delivery of an scFv into Cancer Cells
}

\author{
Ki Jung Lim ${ }^{1}$, Bong Hyun Sung ${ }^{2}$, Ju Ri Shin ${ }^{1}$, Young Woong Lee ${ }^{1}$, Da Jung Kim ${ }^{1}$, Kyung Seok Yang ${ }^{1}$, Sun \\ Chang Kim ${ }^{1 *}$
}

1 Department of Biological Sciences, Korea Advanced Institute of Science and Technology, Daejeon, Korea, 2 Biochemicals and Synthetic Biology Research Center, Korea Research Institute of Bioscience and Biotechnology, Daejeon, Korea

\begin{abstract}
Cell-penetrating peptides (CPPs) have proven very effective as intracellular delivery vehicles for various therapeutics. However, there are some concerns about non-specific penetration and cytotoxicity of CPPs for effective cancer treatments. Herein, based on the cell-penetrating motif of an anticancer peptide, buforin Ilb, we designed several CPP derivatives with cancer cell specificity. Among the derivatives, a 17-amino acid peptide (BR2) was found to have cancer-specificity without toxicity to normal cells. After specifically targeting cancer cells through interaction with gangliosides, BR2 entered cells via lipid-mediated macropinocytosis. Moreover, BR2 showed higher membrane translocation efficiency than the well-known CPP Tat (49-57). The capability of BR2 as a cancer-specific drug carrier was demonstrated by fusion of BR2 to a single-chain variable fragment (scFv) directed toward a mutated K-ras (G12V). BR2-fused scFv induced a higher degree of apoptosis than Tat-fused scFv in K-ras mutated HCT116 cells. These results suggest that the novel cell-penetrating peptide BR2 has great potential as a useful drug delivery carrier with cancer cell specificity.
\end{abstract}

Citation: Lim KJ, Sung BH, Shin JR, Lee YW, Kim DJ, et al. (2013) A Cancer Specific Cell-Penetrating Peptide, BR2, for the Efficient Delivery of an scFv into Cancer Cells. PLoS ONE 8(6): e66084. doi:10.1371/journal.pone.0066084

Editor: Robert W. Sobol, University of Pittsburgh, United States of America

Received November 2, 2012; Accepted May 6, 2013; Published June 11, 2013

Copyright: ( 2013 Lim et al. This is an open-access article distributed under the terms of the Creative Commons Attribution License, which permits unrestricted use, distribution, and reproduction in any medium, provided the original author and source are credited.

Funding: This work was supported by the Intelligent Synthetic Biology Center of Global Frontier Project funded by the Ministry of Education, Science and Technology (2011-0031955). The funders had no role in study design, data collection and analysis, decision to publish, or preparation of the manuscript.

Competing Interests: The authors have declared that no competing interests exist.

* E-mail: sunkim@kaist.ac.kr

\section{Introduction}

The beneficial effects of many newly-discovered potential therapeutic agents, such as proteins, nucleic acids, and hydrophilic drugs, are limited because of their inability to reach the appropriate intracellular targets [1,2]. Thus, numerous approaches such as microinjection, eletroporation, liposomal formulation and the use of viral vectors have been explored to promote efficient drug delivery [3,4]. One major concern about these techniques is their poor cell specificity [4,5]. Therefore, the development of a target-specific drug delivery system is a primary concern for improving the therapeutic efficacy of drugs while reducing their effective doses and side effects [6,7].

Cell-penetrating peptides (CPPs), also referred to as protein transduction domains, have drawn special attention as an alternative intracellular drug delivery vehicle since the discovery of the first CPP, Tat, in 1988 [8]. CPPs are short peptides consisting of fewer than 30 amino acids and composed mostly of basic, positively charged amino acids (e.g. Arg, Lys and His) that have the capacity to translocate through the cell membrane and to deliver a variety of cell-impermeable cargoes across the cellular membrane [9], including proteins [10], nucleic acids [11], siRNA [12], peptide nucleic acids (PNAs) [13], small molecule therapeutics [14], quantum dots [15], and MRI contrast agents [16]. Although the exact mechanism of CPPs is unknown, recent mechanistic studies imply that their cellular uptake results from an initial rapid electrostatic interaction with the plasma membrane followed by endosomal uptake $[17,18]$.
Using CPPs for the intracellular delivery of a wide range of macromolecules is a powerful approach because of their versatility paired with easy functionalization of linked cargoes and the high delivery efficiency into various cell lines, overcoming challenges often faced with other delivery methods $[19,20]$. Therefore, many studies have focused on the development of novel CPPs; the number of available CPPs with different characteristics, such as increased stability and efficient cargo delivery, continues to increase [17].

Although the potential of CPPs as delivery agents is large, their lack of cell specificity, cytotoxic effects and unexpected side effects are major concerns for their development as drug delivery vehicles [21]. For cancer therapy, CPP cell specificity is especially important so that side effects on normal cells are minimized $[22,23]$. Therefore, there is a strong need for the development of cancer-specific and non-toxic CPPs for effective cancer treatments.

We have previously reported that a potent antimicrobial peptide, buforin IIb (RAGLQFPVG[RLLR $]_{3}$ ), has strong cellpenetrating ability and anticancer activity against various cancer cell lines [24,25]. Even though buforin IIb showed selective cytotoxicity against cancer cells, it also affected the viability of normal cells at high concentrations. To develop buforin IIb as an efficient drug delivery vehicle, its cytotoxicity against normal cells should be minimized while maintaining its cancer cell specificity.

In this study, we designed a novel cancer-specific and non-toxic cell-penetrating peptide, BR2, based on the cell-penetrating motif of buforin IIb and studied the potential as an efficient drug 
delivery vehicle into cancer cells by fusing BR2 to a single-chain variable fragment $(\mathrm{scFv})$ antibody against mutated $\mathrm{K}$-ras.

\section{Materials and Methods}

\section{Cell Culture}

Human cervical cancer cell line HeLa, human colon cancer cell line HCT116, mouse melanoma cell line B16/F10, mouse fibroblast cell line NIH 3T3, human keratinocyte cell line HaCat and human fibroblast cell line BJ were all obtained from American Type Culture Collection (ATCC; Manassas, VA) and cultured in a complete medium [Dulbecco's modified eagle medium] (DMEM) supplemented with 10\% fetal bovine serum (FBS), 100 units $/ \mathrm{ml}$ penicillin, $100 \mu \mathrm{g} / \mathrm{ml}$ streptomycin. Cells were grown in humidified conditions at $37^{\circ} \mathrm{C}$ with $5 \% \mathrm{CO}_{2}$.

\section{Peptide Design and Synthesis}

We designed several derivatives of buforin IIb (BR3) by stepwise elimination of the C-terminal regular $\alpha$-helical motif RLLR repeats of buforin IIb to create a cancer cell specific and non-toxic CPP. The designed peptides consisted of different numbers of the C-terminal regular $\alpha$-helical motif RLLR and named BR1 and BR2 (Table 1).

CPPs Tat, BR1, BR2, and BR3 were chemically synthesized (Anygen, Kwangju, Korea) on a MilliGen 9050 peptide synthesizer. The fluorescein moiety (FITG) was attached to the Nterminus via an aminohexanoic acid spacer by treating a resinbound peptide $(0.1 \mathrm{mM})$ with FITC $(0.1 \mathrm{mM})$ and diisopropyl ethyl amine $(0.5 \mathrm{mM})$ in $\mathrm{N}, \mathrm{N}$-Dimethylformamide (DMF) for $12 \mathrm{~h}$. All crude peptides were purified and analyzed by reversedphase high performance liquid chromatography (RP-HPLC) on a C18 column, and the purified peptides were characterized by electrospray ionization mass spectrometry (ESI-MS).

\section{Confocal Laser Scanning Microscopy}

To investigate the cell-penetrating ability and the intracellular distribution of the internalized peptides, live confocal microscopy was performed on three cancer lines (HeLa, HCT116 and B16/ F10) and three normal cell lines (HaCat, BJ and NIH 3T3). Briefly, cells $\left(2 \times 10^{5}\right)$ were plated on a glass coverslip placed in a 6 well plate, grown overnight, and then incubated with FITClabeled peptides ( $5 \mu \mathrm{M}$ for each cell line) for $30 \mathrm{~min}$. The cells were then rinsed three times with phosphate buffered saline (PBS, $\mathrm{pH}$ 7.4), and mounted on microscope slides with fluorescence mounting solution (Dako Corp, Carpinteria, CA). Colocalization of BR2 with lysosomes was observed by using LysoTracker Red DND-99 (Molecular Probe, Eugene, OR). To avoid the effects of fixation artifacts, involving both methanol and paraformaldehyde, cells were not fixed [26,27]. The distribution of FITC-labeled peptides was analyzed using a confocal scanning laser Zeiss LSM

Table 1. Amino acid sequences of peptides used in this study.

\begin{tabular}{lllll}
\hline & & & \\
\hline Peptides & Amino acid sequence & Charge & Ref. \\
\hline Tat (49-57) & RKKRRQRRR (9 aa) & +8 & {$[46]$} \\
Buf Ilb [BR3] & RAGLQFPVGRLLRLLRRLL (21 aa) & +7 & {$[47]$} \\
BR2 & RAGLQFPVGRLLRLLR (17 aa) & +5 & This study \\
BR1 & RAGLQFPVGRLR (13 aa) & +3 & This study \\
\hline $\begin{array}{l}\text { Underline indicates the model } \alpha \text {-helical sequence. } \\
\text { doi:10.1371/journal.pone.0066084.t001 }\end{array}$ & & &
\end{tabular}

510 microscope (Jena, Germany) equipped with a $40 \times$ and $20 \times$ objective. Fluorophores were excited with an argon laser $(488 \mathrm{~nm})$ for FITC and a HeNe laser (543 nm) for LysoTracker Red.

\section{In vitro Cytotoxicity Assay}

The cytotoxicity of peptides to mammalian cells was investigated by assessing the release of lactate dehydrogenase $(\mathrm{LDH})$ from cancer and normal cells. The amount of $\mathrm{LDH}$ released from damaged cells into the supernatant was measured using the Cytotoxicity Detection Kit (Roche Applied Science, Germany) according to the manufacturer's instructions. In brief, cells were plated onto 96-well microplates $\left(1 \times 10^{4}\right.$ cells per well $)$ in complete DMEM supplemented with $10 \%$ FBS and incubated overnight at $37^{\circ} \mathrm{C}$ to allow for attachment and spreading of cells. After $24 \mathrm{~h}$ of incubation, cells were treated with various concentrations of peptides $(0-100 \mu \mathrm{M})$ and incubated for another $24 \mathrm{~h}$ at $37^{\circ} \mathrm{C}$. The extracellular medium from each well was transferred to a new microplate and incubated for $10 \mathrm{~min}$ with $100 \mu \mathrm{l} /$ well reaction mixture, followed by a stop solution. Absorbance was measured at $490 \mathrm{~nm}$ by using an ELISA plate reader. LDH release from cells lysed with $0.2 \%$ Triton X-100 in PBS was defined as $100 \%$ leakage and $\mathrm{LDH}$ release from untreated cells as $0 \%$ leakage.

\section{Hemolysis Assay}

Hemolytic activity was assayed as described by Aboudy et al. with slight modifications [28]; $3 \mathrm{ml}$ of freshly prepared human erythrocytes was washed with isotonic PBS, pH 7.4, until the color of the supernatant turned clear. The washed erythrocytes were then diluted to a final volume of $20 \mathrm{ml}$ with the same buffer. Peptide samples $(10 \mu \mathrm{l})$, serially diluted in PBS, were added to $190 \mu \mathrm{l}$ of the cell suspension in microcentrifuge tubes. Following gentle mixing, the tubes were incubated at $37^{\circ} \mathrm{C}$ for $30 \mathrm{~min}$ and then centrifuged at $4,000 \times \mathrm{g}$ for $5 \mathrm{~min}$. The supernatant $(100 \mu \mathrm{l})$ was removed to a new tube and the absorbance at $567 \mathrm{~nm}$ was determined. The relative optical density, as compared with that of the cell suspension treated with $0.2 \%$ Triton $\mathrm{X}-100$, was defined as percentage of hemolysis. The hemolysis percentage was calculated using the following equation: percentage hemolysis $=[$ (Abs $567 \mathrm{~nm}$ in the peptide solution - Abs $567 \mathrm{~nm}$ in PBS)/(Abs $567 \mathrm{~nm}$ in $0.2 \%$ Triton X-100 - Abs $567 \mathrm{~nm}$ in PBS)] $\times 100$.

\section{Characterization of Peptide Uptake}

To evaluate the internalization of FITC-labeled peptides, HeLa cells were seeded onto 12 -well plates at a density of $2 \times 10^{5}$ cells per well and incubated for $24 \mathrm{~h}$. FITC-labeled peptides, at various concentrations ranging from 2 to $10 \mu \mathrm{M}$, were then incubated with the cells for $30 \mathrm{~min}$ at $37^{\circ} \mathrm{C}$. To compare the cellular uptake of peptides, cancer and normal cells were treated with FITClabeled peptides (each, $10 \mu \mathrm{M}$ ) and incubated for $30 \mathrm{~min}$ at $37^{\circ} \mathrm{C}$. Following the incubation, cells were washed three times with icecold PBS to remove excess extracellular complexes. Next, the cells were treated with trypsin $(1 \mathrm{mg} / \mathrm{ml})$ for $10 \mathrm{~min}$ to remove any remaining peptides bound to the cell surface. After trypsinization, the cells were collected by centrifugation $(1,000 \times \mathrm{g}$ for $5 \mathrm{~min})$, resuspended with $500 \mu \mathrm{l}$ ice-cold $2 \%$ FBS/PBS containing propidium iodide $(\mathrm{PI})$, and then immediately analyzed $(10,000$ events/sample) by fluorescence activated cell sorting (FACS).

To understand further the cell-penetrating mechanism of peptides, the effects of temperature and metabolic inhibitors were examined. To elucidate the temperature dependency, HeLa cells were incubated at $4^{\circ} \mathrm{C}$ for $30 \mathrm{~min}$ prior to the addition of the peptides. Next, cells were treated with FITC-labeled peptides (each, $5 \mu \mathrm{M}$ ) at $4^{\circ} \mathrm{C}$ for $30 \mathrm{~min}$. For the energy-depletion study, HeLa cells were preincubated with sodium azide $\left(\mathrm{NaN}_{3}, 10 \mathrm{mM}\right)$ 
at $37^{\circ} \mathrm{C}$ for $1 \mathrm{~h}$ and then incubated with FITC-labeled peptides (each, $5 \mu \mathrm{M}$ ) at $37^{\circ} \mathrm{C}$ for $30 \mathrm{~min}$.

To study the role of endocytosis in peptide uptake, cells were pretreated with several endocytosis inhibitors at $37^{\circ} \mathrm{C}$ for $1 \mathrm{~h}$ : (i) amiloride $(5 \mathrm{mM})$, which is known to block macropinocytosis by inhibiting a sodium channel; (ii) nocodazole $(100 \mathrm{ng} / \mathrm{ml})$, which inhibits the clathrin-mediated pathway; and (iii) methyl-ß-cyclodextrin (MBCD, $5 \mathrm{mM}$ ), which inhibits lipid raft-mediated processes by depleting cholesterol from the plasma membrane [29]. All inhibitors were purchased from Sigma (St. Louis, MO).

To examine the effects of negatively charged components on the cell surface for peptide internalization, HeLa cells were pretreated with gangliosides (monosialoganglioside GM3 from canine blood), heparin sulfate, or sialic acid (Neu5Ac, all from Sigma) $(20 \mu \mathrm{g} / \mathrm{ml})$ for $30 \mathrm{~min}$. For the inhibition of ganglioside biosynthesis, cells were pretreated with D-threo-1-phenyl-2-hexadecanoyl amino-3morpholino-1-propanol (PPMP, $5 \mu \mathrm{M}$ ) for $48 \mathrm{~h}$.

For all of these experimental conditions, flow cytometry analyses were performed with live cells using a Becton Dickinson FACSCalibur flow cytometer (BD Biosciences, San Diego, CA). In each case, the fluorescence of 10,000 viable cells was acquired. Viable cells were gated based on a sideward and forward scatter. For data analysis, WinMDI software (Joe Trotter, Scripps Research Institute, La Jolla, CA) was used. The statistical significance was evaluated by Student's t-test at a $95 \%$ confidence interval.

\section{Cloning and Expression of Peptide-fusion Proteins}

To employ BR2 as a vehicle for the delivery of therapeutic proteins, a cDNA of the Y13-259 single-chain variable fragment $(\mathrm{scFv})$ gene was synthesized at Bioneer (Daejeon, Korea). The Tator BR2-fused Y13-259 scFv genes were obtained by recombinant PCR. The recombinant cDNAs encoding the anti-Ras scFv, Tat$\mathrm{scFv}_{\mathrm{V}}$ and $\mathrm{BR} 2-\mathrm{scFv}$ fusions were digested with $\mathcal{N}_{c o} \mathrm{I}$ and $E c o R \mathrm{I}$ (both from New England Biolabs, Beverly, MA), and cloned into the $\mathcal{N}_{c o} \mathrm{I}$ and $E c_{0} R \mathrm{I}$ sites of pET2lc, producing pscFv, pTat-scFv and pBR2-scFv, respectively. Anti-Ras scFv, Tat-scFv and BR2$\mathrm{scF}_{\mathrm{V}}$ fusion proteins were expressed in E. coli Origami (DE3) after induction with $0.1 \mathrm{mM}$ IPTG for $4 \mathrm{~h}$ at $37^{\circ} \mathrm{C}$. Cells were harvested by centrifugation at $3,000 \times \mathrm{g}$ for $15 \mathrm{~min}$ at $4^{\circ} \mathrm{C}$. The cell pellet was resuspended in phosphate buffer $(10 \mathrm{mM}$ sodium phosphate, $150 \mathrm{mM} \mathrm{NaCl}, \mathrm{pH} \mathrm{7.4);} \mathrm{cells} \mathrm{were} \mathrm{disrupted} \mathrm{by}$ sonication at $4^{\circ} \mathrm{C}$ (B. Braun instruments, Allentown, PA). The protease inhibitor phenylmethylsulfonyl fluoride (PMSF, $1 \mathrm{mM}$ ) was added prior to sonication. The soluble and insoluble fractions were separated by centrifugation at $14,000 \times \mathrm{g}$ for $15 \mathrm{~min}$ at $4^{\circ} \mathrm{C}$. The pellet containing the inclusion bodies was resuspended in wash buffer $(20 \mathrm{mM}$ Tris- $\mathrm{HCl}, 5 \mathrm{mM}$ EDTA and $1 \%$ Triton X$100, \mathrm{pH} 8.0$ ) and centrifuged at $8,000 \times \mathrm{g}$ for $10 \mathrm{~min}$ at $4^{\circ} \mathrm{C}$.

The washed inclusion bodies were denatured and solubilized in lysis buffer $(0.3 \%$ N-lauroyl sarcosine, $50 \mathrm{mM}$ CAPS buffer, and $0.3 \mathrm{M} \mathrm{NaCl}, \mathrm{pH} 11.0$ ) for $3 \mathrm{~h}$ and centrifuged at $14,000 \times \mathrm{g}$ for $15 \mathrm{~min}$ at $4^{\circ} \mathrm{C}$. All proteins were affinity-purified by using the $\mathrm{Ni}-$ IDA agarose resin (ELPIS biotech, Daejeon, Korea). In brief, the Ni-IDA His-Bind Resin was packed into a column equilibrated with binding buffer (identical to lysis buffer). The supernatant was slowly applied to the column, after which wash buffer $(0.3 \% \mathrm{~N}$ lauroyl sarcosine, $50 \mathrm{mM}$ CAPS buffer, $150 \mathrm{mM} \mathrm{NaCl}$, and $30 \mathrm{mM}$ imidazole, $\mathrm{pH} 11.0$ ) was applied. The proteins were eluted with elution buffer $(0.3 \% \mathrm{~N}$-lauroyl sarcosine, $50 \mathrm{mM}$ CAPS buffer, $150 \mathrm{mM} \mathrm{NaCl}$, and $250 \mathrm{mM}$ imidazole, $\mathrm{pH} \mathrm{11.0)}$ and analyzed by $10 \%$ SDS-PAGE. The eluted proteins were refolded by dialysis in PBS containing $200 \mathrm{mM} \mathrm{NaCl}, 10 \%$ glycerol, $1 \mathrm{mM}$ $\mathrm{GSH}, 0.2 \mathrm{mM}$ GSSG and $0.4 \mathrm{M}$ arginine with gradual $\mathrm{pH}$ reduction ( $\mathrm{pH} 10, \mathrm{pH} 9, \mathrm{pH} 8$ and $\mathrm{pH}$ 7.4). Each dialysis step was performed at $4^{\circ} \mathrm{C}$ for $12 \mathrm{~h}$ against $20 \times$ sample volume to remove the detergent completely.

\section{Western Blotting}

To monitor the peptide-mediated intracellular uptake of $\mathrm{scF}_{\mathrm{V}}$ proteins, the internalized fusion proteins were examined by Western blotting. HCT 116 cells $\left(1 \times 10^{6}\right)$ were treated with PBS, purified $\mathrm{scF}_{\mathrm{v}}$, Tat-scFv, or BR2-scFv fusion proteins (each, $2 \mu \mathrm{M}$ ) for $2 \mathrm{~h}$ at $37^{\circ} \mathrm{C}$. The cells were then washed twice with PBS $\left(4^{\circ} \mathrm{C}\right)$, scraped into $0.5 \mathrm{ml}$ of PBS and centrifuged at $1,000 \times \mathrm{g}$ at $4^{\circ} \mathrm{C}$ for $5 \mathrm{~min}$. The cell pellets were resuspended in $100 \mu \mathrm{l}$ of lysis buffer (20 mM Tris-HCl (pH 7.5), $150 \mathrm{mM} \mathrm{NaCl,} 1 \mathrm{mM} \mathrm{Na} 2$ EDTA, $1 \mathrm{mM}$ EGTA, $1 \%$ Triton, $2.5 \mathrm{mM}$ sodium pyrophosphate, $1 \mathrm{mM}$ beta-glycerophosphate, $1 \mathrm{mM} \mathrm{Na} \mathrm{VO}_{4}, 1 \mu \mathrm{g} / \mathrm{ml}$ leupeptin and $1 \mathrm{mM}$ PMSF (Cell Signaling Tech., Danvers, MA) and kept on ice for $30 \mathrm{~min}$. The cell lysates were then centrifuged at $12,000 \times \mathrm{g}$ at $4^{\circ} \mathrm{C}$ for $15 \mathrm{~min}$ and the supernatants were collected. Protein concentrations in the cell extracts were determined by the Bradford method [30] (Bio-Rad, Hercules, CA). $50 \mu \mathrm{g}$ of protein from cell extracts was fractionated on a $10 \%$ SDS-PAGE gel. After electrophoresis, proteins were transferred onto a nitrocellulose membrane in transfer buffer $(192 \mathrm{mM}$ glycine, $25 \mathrm{mM}$ Tris-HCl, $\mathrm{pH} 8.8$, and $20 \%$ methanol [v/v]) by electroblotting. After blocking with $5 \%$ skim milk for $1 \mathrm{~h}$, the membrane was incubated with a 1:1,000-diluted anti-His primary antibody (Santa Cruz Biotechnology, Santa Cruz, CA), washed three times with TTBS (50 mM Tris, $150 \mathrm{mM} \mathrm{NaCl}$, and $0.5 \%$ Tween-20), and subsequently incubated with a peroxidase-conjugated anti-rabbit secondary antibody (GE Healthcare, Uppsala, Sweden) in milk containing TTBS for $1 \mathrm{~h}$. After final washing, the membrane was then exposed and protein bands were detected using Enhanced Chemiluminescence (WESTSAVE GOLD; AbFrontier, Seoul, Korea).

\section{Cell Proliferation Assays (MTT Assay)}

To assess the anti-proliferative activity of peptides and anti-Ras $\mathrm{scF}$ v fusion proteins, HCT116 cells (K-ras mutated cells) were seeded in 96-well plates at a density of $2 \times 10^{4}$ cells/well in $100 \mu \mathrm{L}$ of DMEM supplemented with $10 \%$ FBS and cultured for $24 \mathrm{~h}$ at $37^{\circ} \mathrm{C}$. After $24 \mathrm{~h}$ of incubation, cells were treated with $\mathrm{scFv}$ or peptide-scFv fusion proteins $(0,0.5,1$ and $2 \mu \mathrm{M})$ and incubated for another $24 \mathrm{~h}$. Cell viability was measured with the 3-(4,5dimethylthiazol-2-yl)-2,5-diphenyl tetrazolium bromide (MTT) assay using the CellTiter $96^{\circledR}$ Non-radioactive Cell Proliferation assay kit (Promega, Madison, WI) according to the manufacturer's instructions. The absorbance of the solution was measured at $570 \mathrm{~nm}$ using a Microplate Reader (Bio-Rad). Cell viability was expressed as the percentage of viable cells treated with $\mathrm{scF}_{\mathrm{V}}$ or peptide-scFv fusion proteins compared to the PBS-treated control $(100 \%)$. All experiments were done in triplicate.

\section{Detection of Apoptosis}

HCT 116 cells $\left(1 \times 10^{6} /\right.$ well in a 6 -well plate) were treated with peptide-fused scFvs (each, $2 \mu \mathrm{M}$ ) or a well-known apoptosis inducer staurosporine $(0.5 \mu \mathrm{M})$ for $24 \mathrm{~h}$ at $37^{\circ} \mathrm{C}$ and cell extracts were prepared as described above. Cleaved poly (ADP ribose) polymerase (PARP), an indicator of apoptosis, was detected by Western blotting as described above. Anti-PARP and anti- $\alpha-$ tubulin antibodies (Cell Signaling Tech.) were used at a 1:1,000 dilution as the primary antibodies, whereas horseradish peroxidase-conjugated anti-rabbit IgG (GE Healthcare, Uppsala, Sweden) was used at a 1:10,000 dilution as the secondary antibody. 
In addition, apoptotic cells were identified by staining with annexin V-FITC $(150 \mathrm{ng} / \mathrm{ml})$ and 7 amino-actinomycin D (7AAD; BD Biosciences, San Diego, CA). $1 \times 10^{6}$ HCT116 cells were treated with PBS, staurosporine $(0.5 \mu \mathrm{M})$, or peptide-fused scFvs (each, $2 \mu \mathrm{M}$ ) as described above. At the designated time, cells were washed twice with PBS ( $\mathrm{pH} 7.4)$, harvested and resuspended in $500 \mu \mathrm{l}$ of binding buffer supplemented with Annexin-V fluos (1:100 diluted; BioBud, Seoul, Korea), and incubated for $15 \mathrm{~min}$ at $25^{\circ} \mathrm{C}$ in the dark. To detect necrosis, 7AAD was added prior to measurement. Samples were immediately subjected to FACS analysis with a FACSCalibur flow cytometer (FL1 and FL3) and WinMDI software (Joe Trotter, Scripps Research Institute). $1 \times 10^{4}$ cells per sample were analyzed by flow cytometry.

\section{Ras Activation Assay}

To study the peptide-scFv fusion protein-dependent suppression of Ras activity, the level of Ras-GTP (active form) was measured using a Ras activation assay kit (Millipore, Billecia, MA) according to the manufacturer's instructions. This method is based on a selective binding of Ras-GTP using the Ras binding domain (RBD) of Raf-1 (a kinase downstream of Ras) that fails to bind Ras-GDP (inactive form). Briefly, $50 \mu \mathrm{l}$ of RBD protein fused to glutathione transferase (GST) was coated on to a 96-well glutathione-coated plate at $4{ }^{\circ} \mathrm{C}$ for $1 \mathrm{~h}$ and washed with TBST (50 mM Tris, $150 \mathrm{mM} \mathrm{NaCl}$, and 0.05\% Tween-20, pH 7.6). HCT 116 cells were treated with $\mathrm{scFv}$, Tat-scFv, or BR2-scFv for 1 or $2 \mathrm{~h}$, after which cells were lysed using $1 \times \mathrm{Mg}^{2+}$ Lysis/Wash Buffer (Millipore). The protein concentration was calculated by the Bradford assay. Cell lysates containing $50 \mu \mathrm{g}$ of protein were incubated for $1 \mathrm{~h}$ in the RBD-GST-coated wells at $25^{\circ} \mathrm{C}$. After washing three times with TBST, primary antibody solution was added and incubated at $4^{\circ} \mathrm{C}$ for $1 \mathrm{~h}$. After washing with TBST, the secondary HRP-conjugated anti-mouse antibody was added and incubated at $25^{\circ} \mathrm{C}$ for $1 \mathrm{~h}$. After a final washing with TBS (50 mM Tris, $150 \mathrm{mM} \mathrm{NaCl,} \mathrm{pH} \mathrm{7.6),} 50 \mu \mathrm{l}$ of the Chemiluminescent substrates was added to each well. Chemiluminescence signals from each well were monitored using the Berthold luminometer (MicroLumat LB96P; Berthold Technologies, Oak Ridge, TN). Results were expressed as relative Ras activity.

\section{Results}

BR2 Efficiently Internalizes into Various Cancer Cell Lines without Cytotoxicity to Normal Cells

The cellular uptake and intracellular distribution of the designed peptides, BR1 and BR2, were studied using confocal microscopy. BR2 was readily internalized into cancer cells (HeLa, HCT116 and B16/F10) within $30 \mathrm{~min}$ and distributed throughout the cytoplasm and nucleus of cancer cells (Fig. 1A). However, it was very poorly internalized into normal cells (HaCat, BJ and NIH 3T3) under the same experimental conditions. In contrast, BR1 displayed negligible cellular uptake levels in both cancer and normal cells, indicating that it could not translocate across the cell membrane (Fig. 1A). Fluorescence from Tat-treated cells was also clearly detected in both the nucleus and cytoplasm of cancer and normal cells. More Tat accumulated in the nucleus than cytoplasm, whereas most BR2 was evenly distributed in the intracellular regions (Fig. 1A).

To assess the in vitro cytotoxicity of the designed peptides, the LDH leakage was measured in cancer cell lines (HeLa, HCT116 and B16/F10) and normal cell lines (HaCat, BJ and NIH 3T3). BR2 treatment $(20-100 \mu \mathrm{M})$ was associated with $\mathrm{LDH}$ leakage from cancer cells; the leakage gradually increased with BR2 concentrations, reaching about $40-60 \%$ at $100 \mu \mathrm{M}$ (Fig. 1B $a-c)$.
However, LDH leakage from the BR2-treated normal cells was not detected at BR2 concentrations below $70 \mu \mathrm{M}$, and a weak leakage $(\sim 17 \%)$ was observed at $100 \mu \mathrm{M}$ (Fig. 1B $d-f)$. BR3 induced substantial LDH leakage from both cancer (approx. 80$90 \%$ ) and normal cell lines (approx. 30\%) even at $50 \mu \mathrm{M}$ (Fig. 1B $a-f)$.

To examine the cytotoxicity of peptides further, the hemolytic activity of BR1, BR2, BR3 and Tat against human erythrocytes was also examined. In accordance with the LDH leakage results, no hemolysis was induced even after the erythrocytes were treated with Tat, BR1 or BR2 at $\geq 200 \mu \mathrm{M}$, whereas BR3 triggered hemolysis ( $\geq 5 \%$ ) at $\geq 25 \mu \mathrm{M}$ (Fig. 1C). Subsequently about $34.3 \%$ of erythrocytes were lysed after being treated with $200 \mu \mathrm{M}$ BR3. Taken together, these results indicate that BR2 efficiently penetrates cancer cells without cytotoxic effects in normal cells, whereas Tat showed similar penetration into both cell types.

\section{BR2 Specifically Penetrates Cancer Cells in a Concentration-dependent Manner}

To compare the quantity of the internalized peptides in different cell types, we performed flow cytometric analysis. BR2 was internalized more efficiently into cancer cells (HeLa, HCT116 and B16/F10) than into normal cells (HaCat, BJ and NIH 3T3); more than $95 \%$ of BR2-treated cancer cells internalized BR2, whereas only $23-34 \%$ of BR2-treated normal cells did. However, Tat penetrated both cancer and normal cells without much discrimination (Fig. 2A). Specific penetration of BR2 and Tat into cancer cells was also analyzed in the presence of both HeLa and BJ fibroblast cells by confocal laser microscopy. BR2 was preferentially uptaken by HeLa cells, whereas the cellular uptake of Tat was similar in both HeLa and BJ fibroblast cells (Fig. S1). These results clearly show that the buforin-derivative BR2 has cancer cell specificity, whereas Tat does not.

The fluorescence intensity of peptide-treated cells was enhanced with increasing concentrations of BR2 or Tat. At concentrations above $5 \mu \mathrm{M}$, BR2 entered more than $80 \%$ of HeLa cells within 30 min (Fig. 2B). BR2 penetrated cells more efficiently than did the Tat peptide at every tested concentration. Moreover, BR2 internalization for all cancer cell lines (HCT116 and B16/F10, data not shown) appeared to be homogeneous in the whole cell population as a single peak on the histogram. Among the peptides, BR1 displayed the lowest uptake, indicating its inability to penetrate the cell membrane even at $10 \mu \mathrm{M}$.

\section{Initial Electrostatic Interaction with Positively Charged BR2 and Negatively Charged Gangliosides on the Cancer Cell Membrane is Essential for the Energy-dependent Endocytosis of BR2 \\ The cellular uptake mechanism of BR2 was analyzed with} HeLa, the most representative and widely used cancer cell line, to compare with those of other cell-penetrating peptides. We first examined the effect of temperature on BR2 penetration. Lowering the temperature dramatically reduced peptide uptake in HeLa cells (Fig. 3A); the cellular uptake of BR2 and Tat at $4^{\circ} \mathrm{C}$ was decreased by $88.5 \%$ and $31.6 \%$, respectively, compared to that observed at $37^{\circ} \mathrm{C}$. In addition, an energy-dependent uptake of peptides was also observed when the cellular ATP pool was depleted by preincubation of the cells with sodium azide $\left(\mathrm{NaN}_{3}\right)$. ATP depletion also reduced the uptake of BR2 and Tat in HeLa cells, by $67.7 \%$ and $42.5 \%$, respectively (Fig. 3A). These results support the involvement of endocytosis for BR2 and Tat uptake.

We next determined whether the cellular uptake of BR2 occurs through a specific endocytic pathway. Depletion of cholesterol 
A

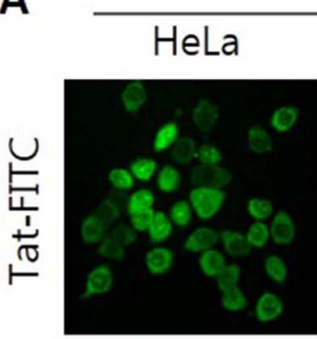

Cancer cells
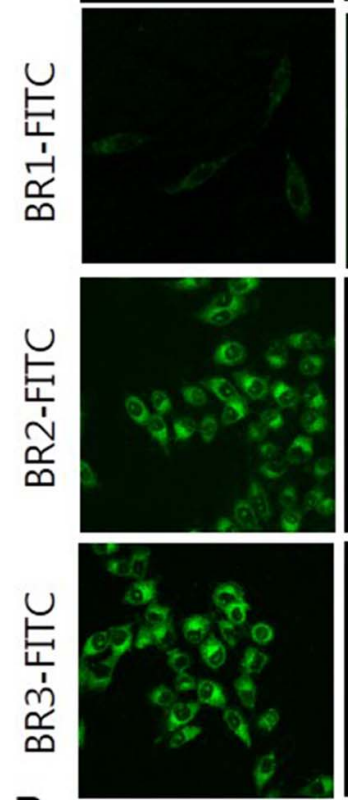

B
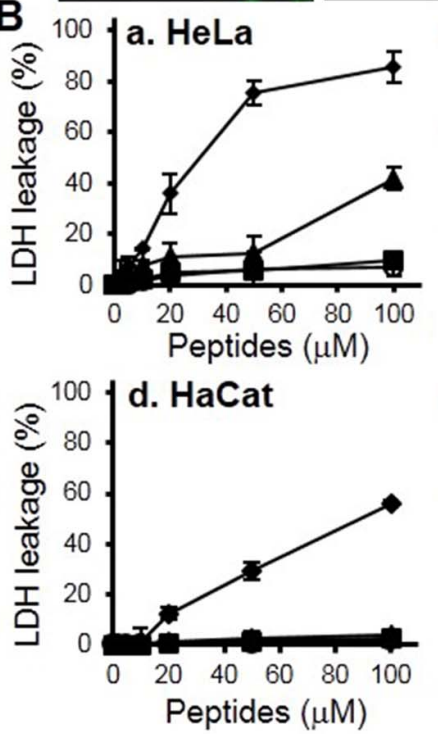

HCT116
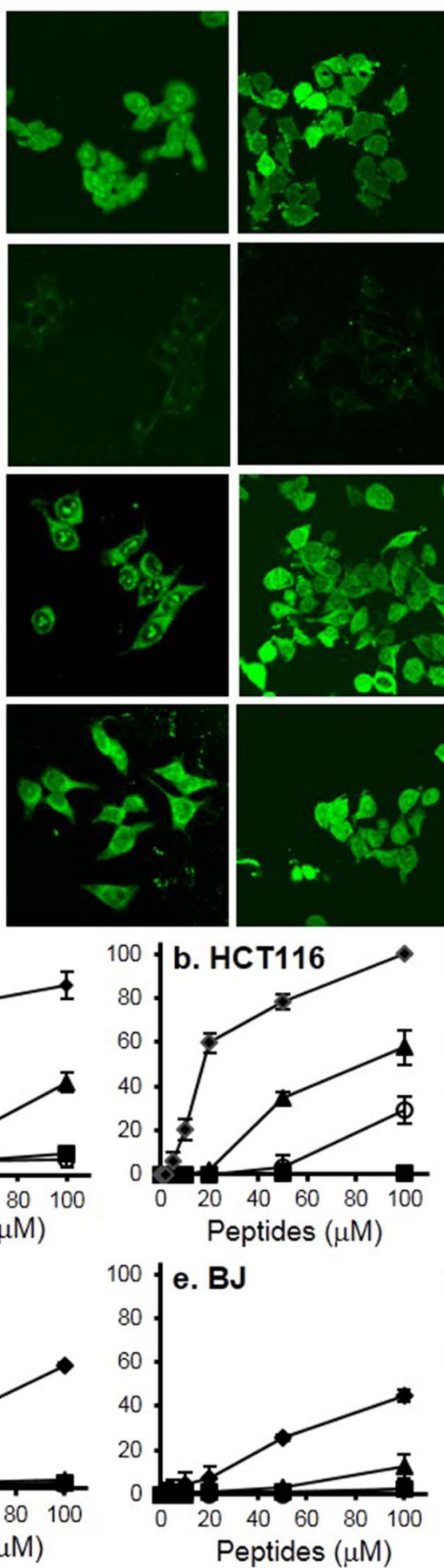

Normal cells
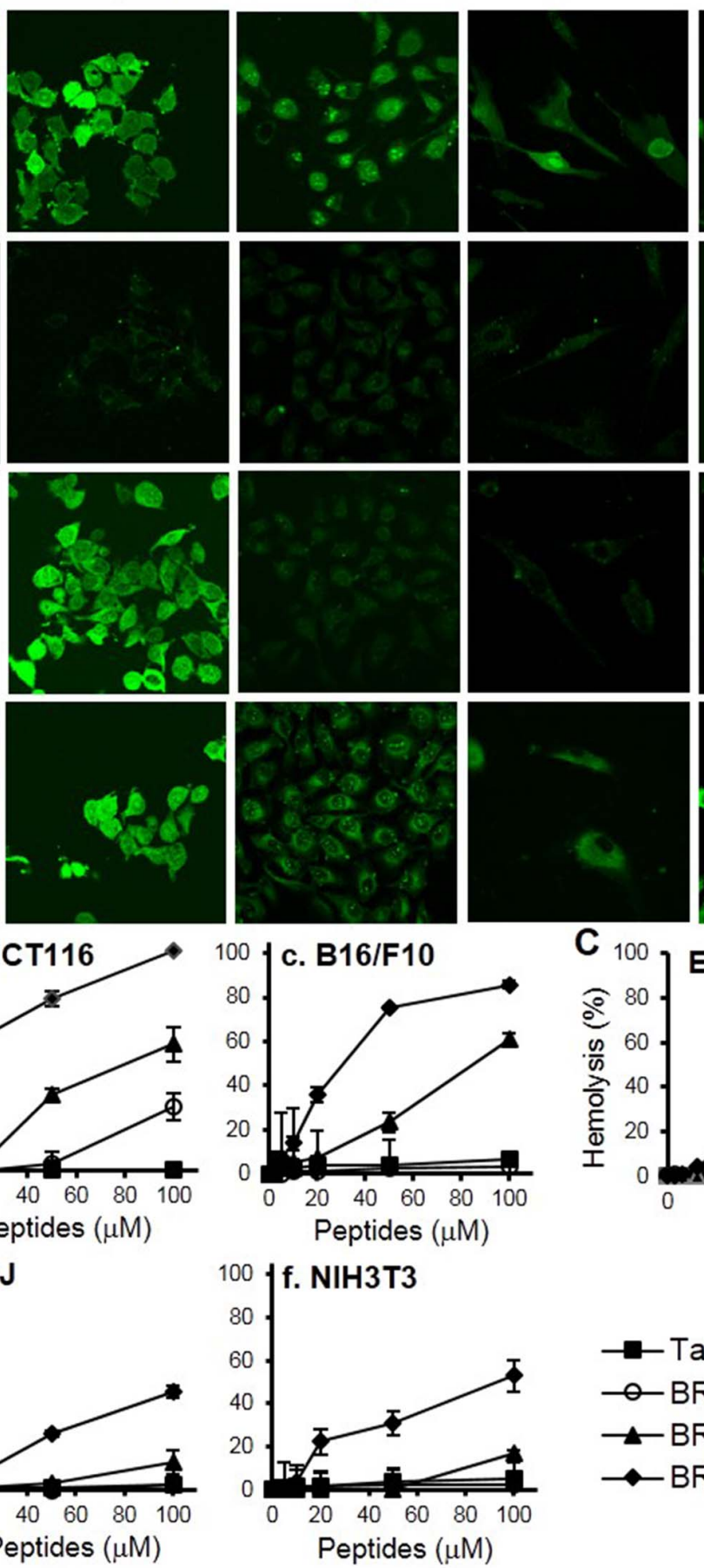

NIH3T3
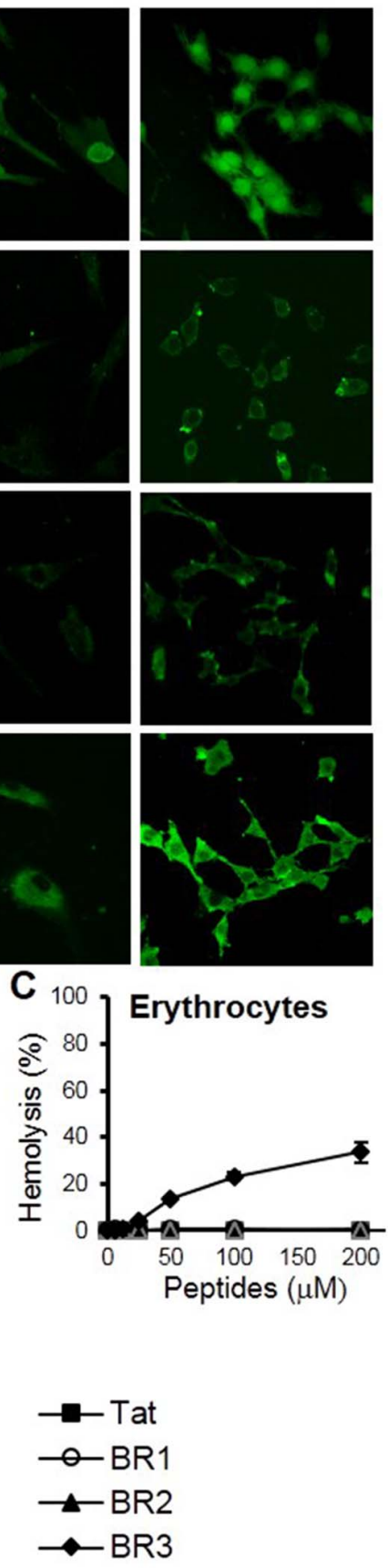

Figure 1. BR2 efficiently translocates into various cancer cells without cytotoxicity to normal cells. (A) Intracellular distribution of FITClabeled peptides examined by confocal laser microscopy. Both cancer cells (HeLa, HCT116 and B16/F10) and normal cells (HaCat, BJ and NIH 3T3) were seeded in 6-well plates 1 day prior to the experiment to reach $70 \%$ confluence. Cells were incubated with FITC-labeled peptides ( $5 \mu \mathrm{M}$ ) for $30 \mathrm{~min}$ at $37^{\circ} \mathrm{C}$ and washed three times with phosphate buffered saline (PBS). Peptide distribution was then analyzed using a confocal scanning LSM 510 laser microscope equipped with a $40 \times$ objective. (B,C) In vitro cytotoxicity of peptides. (B) Membrane disturbance was measured by lactate dehydrogenase (LDH) leakage from the indicated cell lines $24 \mathrm{~h}$ after peptide treatment. LDH leakage from cells seeded in a $96-\mathrm{well}$ plate at 10,000 cells/well was measured after exposure to $1,2,5,10,20,50$ or $100 \mu \mathrm{M}$ peptides for $24 \mathrm{~h}$. LDH release from PBS treated cells was regarded as $0 \%$ leakage and $\mathrm{LDH}$ released from $0.2 \%$ Triton X-100 treated cells as $100 \%$ leakage. (C) The hemolytic activity of each peptide against human erythrocytes was analyzed at graded concentrations $(0-200 \mu \mathrm{M})$ and compared to a $0.2 \%$ Triton X-100 positive control, for which hemolysis was defined as $100 \%$. Error bars in all figures represent the standard errors of the means $(n=3)$.

doi:10.1371/journal.pone.0066084.g001 

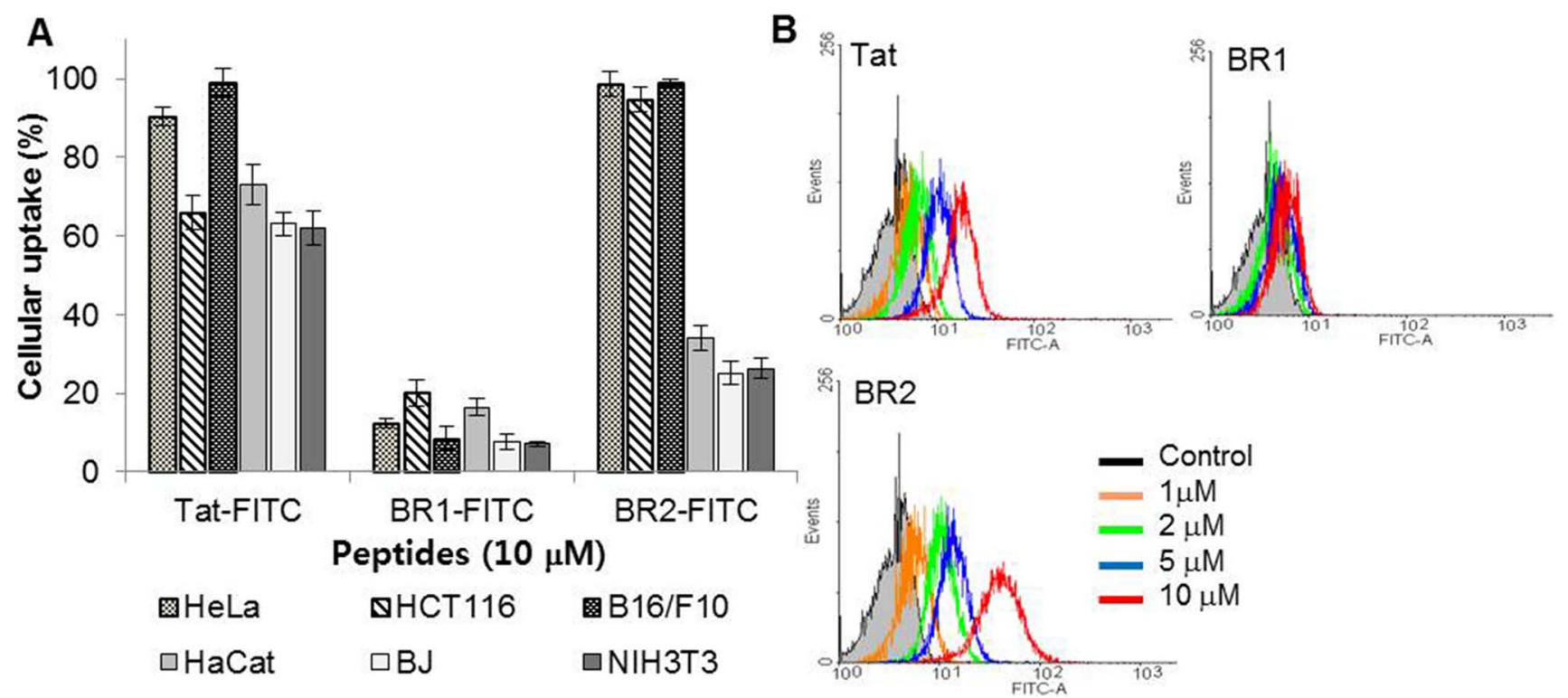

Figure 2. BR2 specifically penetrates cancer cell membranes in a concentration-dependent manner. (A) Analysis of the cell-penetrating efficiency of each peptide in different cell types by flow cytometry. FITC-labeled Tat, BR1 and BR2 peptides $(10 \mu \mathrm{M})$ were added to different cell types: HeLa, HCT116 and B16/F10 cancer cells and HaCat, BJ and NIH 3 T3 normal cells. After 30 min of incubation at $37^{\circ} \mathrm{C}$, the FITC-positive cells were counted by flow cytometry. Values represent the percentage of fluorescence-positive cells in the total cell population. (B) Quantitative assessment of cell penetration of each peptide by flow cytometry. HeLa cells were incubated with FITC-labeled peptides at concentrations of $1,2,5$, or $10 \mu \mathrm{M}$ for $30 \mathrm{~min}$ at $37^{\circ} \mathrm{C}$. Afterwards the cells were washed with cold PBS and harvested and cellular fluorescence was analyzed by flow cytometry. Control cells did not receive peptide treatment. Prior to analysis, extracellular fluorescence of surface bound peptides was removed by a trypsin treatment $(1 \mathrm{mg} / \mathrm{ml}$ for $10 \mathrm{~min}$ ).

doi:10.1371/journal.pone.0066084.g002

from the plasma membrane with methyl-3-cyclodextrin (MBCD) significantly inhibited the penetration of BR2 $(44.6 \%)$ into HeLa cells, suggesting that BR2 penetrates the cell membrane via lipid raft-mediated endocytosis (Fig. 3B). Furthermore, pretreatment of cells with amiloride, a specific inhibitor of a sodium channel required for macropinocytosis, also prevented the cellular uptake of BR2 $(36.5 \%)$. In contrast, pretreatment with nocodazole, an inhibitor of clathrin-mediated endocytosis, showed a negligible effect on peptide transduction. This result indicates that lipid raftmediated macropinocytosis is a major mode of BR2 transduction.

To determine if BR2 is degraded via the lysosomal pathway, codistribution with LysoTracker, an agent that accumulates in late endosomes/lysosomes, was examined. An overlay of respective images showed this lysosomal marker (red) primarily in a random punctuate distribution that was mostly separated from the BR2 signal (green) (Fig. 3C). BR2 was dispersed widely in the cytoplasmic region and the majority of BR2 was not colocalized with lysosomes. These results indicate that BR2 can escape from endosomes into the cytosol, bypassing further steps in the lysosomal pathway.

To identify the initial cell-surface binding targets for BR2 internalization into cancer cells, we examined whether exogenous gangliosides, heparins or sialic acids affected this process. Preincubation of gangliosides and sialic acids with BR2 partially inhibited peptide penetration into HeLa cells, whereas Tat penetration was not affected (Fig. 3D $a$ and $b$ ). However, Tat uptake was severely reduced when heparin was added to the culture medium. Moreover, incubation of HeLa cells with the ganglioside synthesis inhibitor PPMP, significantly reduced BR2 but not Tat uptake (Fig. 3D $c$ and $d$ ). These results indicate that gangliosides on cancer cell membranes are one of the main target molecules for BR2 binding.

\section{BR2-scFv Inhibits Cancer Cell Growth in a Dose- dependent Manner}

The ability of BR2 to deliver proteins into cancer cells (HeLa cells) was demonstrated by fusion with an EGFP. BR2 delivered EGFP more efficiently into cancer cells than Tat (Fig. S2). These results suggest that BR2 can be used to deliver proteins efficiently into cancer cells by fusion with cargo proteins.

To further investigate the effects of BR2 on therapeutic protein delivery into cancer cells, Tat and BR2 were each fused with antiRas $\mathrm{scFv}_{\mathrm{v}}$ (Fig. 4A), and the intracellular penetration of these fusions was assessed by Western blotting. This analysis showed that both Tat- and BR2-scFv fusion proteins were effectively delivered into HCT116 cells and accumulated in the intracellular region within $2 \mathrm{~h}$, whereas the transduction of $\mathrm{scFv}_{\mathrm{V}}$ itself was not observed (Fig. 4B). The amount of BR2-scFv fusion protein delivered into the cytoplasm was $32.6 \%$ more than that of the intracellularly delivered Tat-scFv fusion protein under the same experimental conditions.

Moreover, the intracellular localization of peptides and anti-Ras $\mathrm{scF}_{\mathrm{V}}$ fusion proteins in HCT116 cells was examined by immunocytochemistry analysis. The fluorescence was detected in cytoplasmic regions of Tat- and BR2-scFv treated cells (Fig. S3). Especially, BR2-scFv treated cells showed higher fluorescence intensity than Tat-scFv treated cells, indicating that BR2 delivered scFv more efficiently into cells than Tat did. Unlike Tat- or BR2$\mathrm{scFv}$ fusion proteins, unconjugated $\mathrm{scFv}_{\mathrm{V}}$ was not detected in the cells.

Next, we investigated the anticancer activity of peptide-scFv fusion proteins against Ras-mutated cancer cells by comparing it with the activity of unconjugated $\mathrm{scFv}$ in vitro. A significant reduction of cell viability was observed $24 \mathrm{~h}$ after the introduction of $\mathrm{BR} 2-\mathrm{scF}_{\mathrm{V}}$ or Tat-scFv fusion proteins versus unconjugated $\mathrm{scFv}_{\mathrm{V}}$ 

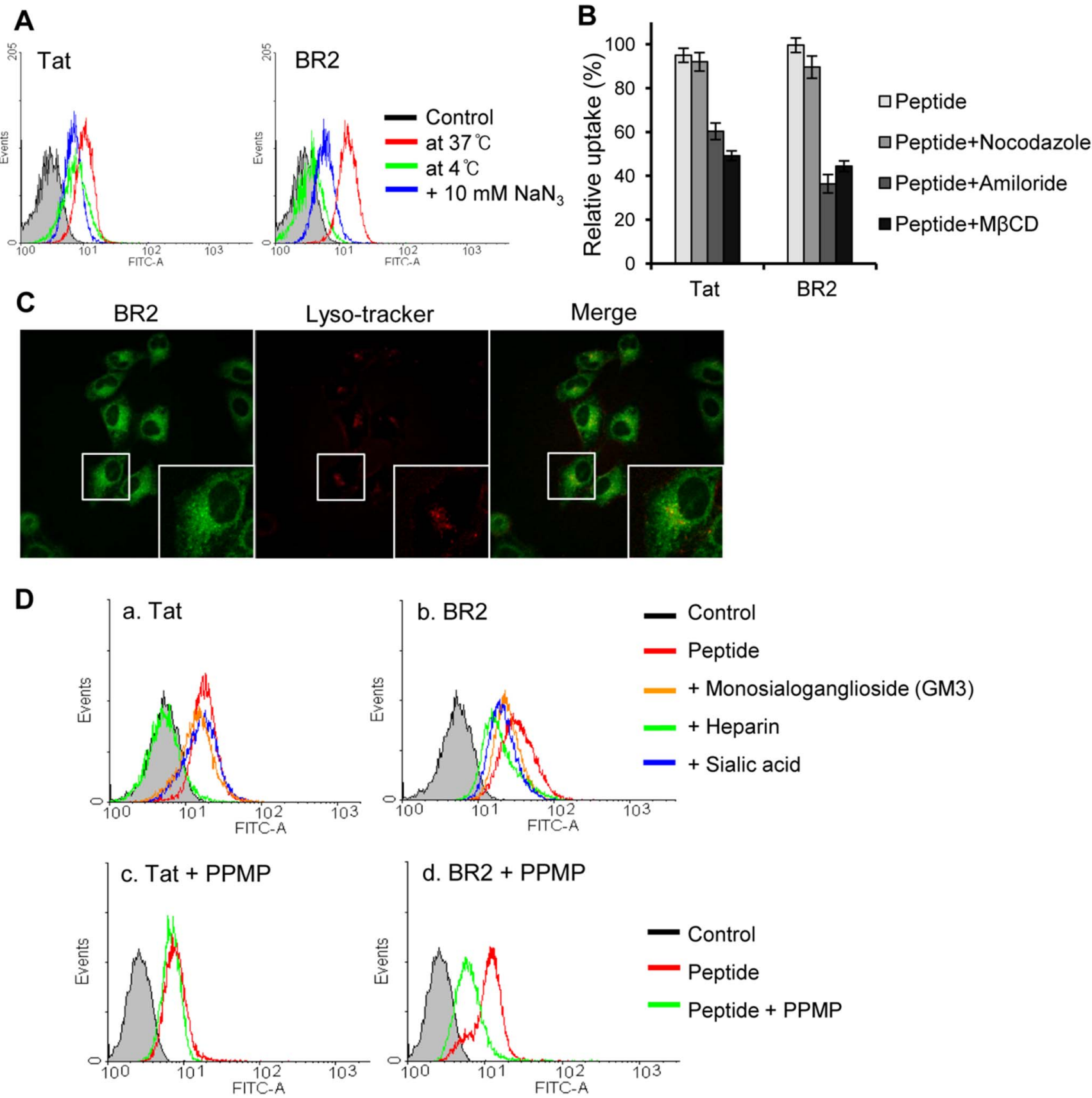

Figure 3. Contribution of energy-dependent pathways and negatively charged molecules on cancer cell membranes to peptide internalization. (A) Effects of low temperature and energy depletion on the internalization of FITC-labeled peptides into HeLa cells. HeLa cells were either preincubated at $4{ }^{\circ} \mathrm{C}$ or pretreated with sodium azide $\left(\mathrm{NaN}_{3}\right)$ to deplete ATP for $1 \mathrm{~h}$, and then incubated with $5 \mu \mathrm{M}$ Tat or BR2 for 30 min under the same conditions, as described in Materials and Methods. Peptide uptake was determined by flow cytometry. (B) Effects of endocytic inhibitors on the entry of BR2 and Tat. The influence of inhibitory drugs on peptide uptake was determined by preincubation of HeLa cells with the endocytosis inhibitors nocodazole, amiloride or methyl-ß-cyclodextrin for $1 \mathrm{~h}$ prior to the addition of FITC-labeled peptides. After peptide treatment for 30 min at $37^{\circ} \mathrm{C}$, FITC-positive cells were counted by flow cytometry. Values represent the percentage of fluorescence-positive cells in the total cell population. Data represent the mean \pm s.d. of three independent experiments. (C) Colocalization of BR2 with the lysosomal marker LysoTracker red DND-99 in living HeLa cells. After 30 min incubation of BR2 $(5 \mu \mathrm{M})$ with LysoTracker, live HeLa cell images were obtained by confocal microscopy. (D) Effects of negatively charged molecules (gangliosides, heparins, and sialic acids) on peptide uptake. (a,b) HeLa cells were treated with BR2 and Tat in the presence of gangliosides, heparins, or sialic acids (each, $20 \mu \mathrm{g} / \mathrm{ml}$ ) for $30 \mathrm{~min}$. In (c,d), HeLa cells were pretreated with PPMP (5 $\mu$ M) to deplete gangliosides. Cellular uptake of BR2 and Tat was determined by flow cytometry. All experiments were performed in triplicate. doi:10.1371/journal.pone.0066084.g003

(Fig. 4C), BR2 or Tat alone (Fig. S4). The viability of $2 \mu \mathrm{M}$ BR2$\mathrm{scF}_{\mathrm{V}}$ treated cancer cells was $39.3 \%$, much lower than that of $\mathrm{scFV}$ or Tat-scFv treated cells, which had viabilities of $87.8 \%$ and
$50.5 \%$, respectively. Inhibition of cell proliferation positively correlated with protein concentration, suggesting that BR2-scFv more efficiently suppresses cancer cell proliferation than Tat-scFv. 


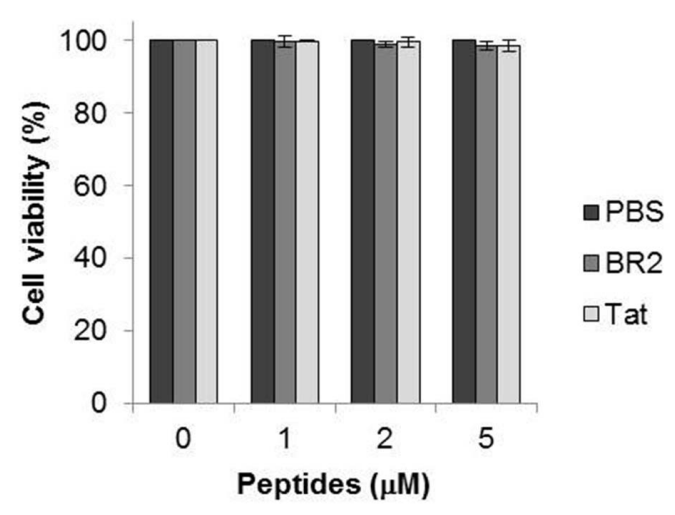

Figure 4. Intracellular uptake of peptides and anti-Ras ScFv fusion proteins and their anti-proliferative activity. (A) Schematic representation of peptide-anti-Ras scFv CDNA constructs. DNA encoding peptides and the Y13-259-scFv cDNA were fused as described in Materials and Methods and cloned into the Ncol and EcoRl sites of pET21c. The white boxes represent $V_{H}$ and $V_{L}$ of the Y13-259 scFv sequence. The round box indicates the sequence encoding the peptides: Tat or BR2. The Ncol and EcoRI restriction sites and stop codon positions are also indicated. (B) Protein uptake was analyzed by Western blotting of fractionated lysates from HCT116 cells treated with PBS, anti-Ras scFv, BR2- or Tat-scFv fusion protein (each, $2 \mu \mathrm{M}$ ) at $37^{\circ} \mathrm{C}$ for $2 \mathrm{~h}$. An anti-His antibody was used to detect intracellular Tat-scFv and BR2-scFv (28-kDa). (C) The anti-proliferative activity of peptides and anti-Ras SCFv fusion proteins. HCT116 cells were exposed to the indicated concentrations of anti-Ras scFv, Tat- or BR2-scFv fusion protein at $37^{\circ} \mathrm{C}$ for $24 \mathrm{~h}$. Cell proliferation was determined using the MTT assay. Data represent the mean \pm s.d. of three independent experiments.

doi:10.1371/journal.pone.0066084.g004

\section{BR2-anti-Ras scFv Fusion Protein Promotes Apoptosis and Inactivates Ras in Ras-mutated Cancer Cells}

To examine how the $\mathrm{BR} 2-\mathrm{scF}$ fusion protein inhibits cancer cell proliferation, we investigated whether apoptosis was induced. $67.7 \%$ of $\mathrm{BR} 2-\mathrm{scFv}$ treated cells and $47.9 \%$ of Tat-scFv treated cells were in the apoptotic stage, versus $5.6 \%$ and $25.3 \%$ of the PBS- and scFv-treated cells, respectively (Fig. 5A). The percentage of $\mathrm{BR} 2-\mathrm{scFV}$ treated cells that were apoptotic was higher than that of staurosporine-treated cells $(61.6 \%)$. The apoptotic pathway induced by $\mathrm{BR} 2-\mathrm{scFv}$ was further investigated by Western blotting. Treatment of HCT1 16 cells with Tat- or BR2-scFv fusion proteins resulted in the cleavage of the $116-\mathrm{kDa}$ PARP protein to the apoptosis-specific 89-kDa fragment after $24 \mathrm{~h}$. A larger amount of the $89-\mathrm{kDa}$ fragment was detected in the $\mathrm{BR} 2-\mathrm{scF}_{\mathrm{V}}$ treated cells as compared to the staurosporine- or Tat-scFv treated cells. However, the cleaved PARP fragment was not detectable in control cells or scFv-treated cells (Fig. 5B).

Next, we performed Ras activation assays that specifically detect activated GTP-bound Ras to obtain evidence for the suppression of Ras activity by peptide-scFv fusion proteins. These peptide-scFv fusion proteins and staurosporine reduced Ras activity similarly in HCT 116 cells. As shown in Fig. 5C, a significant decrease of Ras activity in HCT116 cells was observed both $1 \mathrm{~h}$ and $2 \mathrm{~h}$ after peptide-scFv fusion protein treatment. The activity of Ras-GTP in cells was significantly suppressed by exogenous Tat- and BR2-scFv fusion proteins $(1,2 \mu \mathrm{M})$ in a dose- and time-dependent manner. Even though both Tat- and BR2-scFv fusion proteins induced a remarkable decrease in the levels of GTP-bound Ras, BR2-scFV was more effective than either staurosporine or Tat-scFv. The decreased relative Ras activity in cells treated with $2 \mu \mathrm{M}$ Tat-scFv (about $34 \%$ and $53 \%$ after $1 \mathrm{~h}$ and $2 \mathrm{~h}$, respectively) was roughly similar to that treated with $1 \mu \mathrm{M}$ BR2-scFv (about $27 \%$ and $52 \%$ after $1 \mathrm{~h}$ and $2 \mathrm{~h}$, respectively). Active Ras was decreased by about $67 \%$ when cells were treated with $2 \mu \mathrm{M}$ BR2-scFv for $2 \mathrm{~h}$ (Fig. 5C).

\section{Discussion}

Here, we report that BR2, which is derived from the anticancer peptide buforin IIb, has a potent ability to deliver therapeutic proteins specifically into target cancer cells. Buforin IIb is known for its efficient ability to penetrate cancer cells through an electrostatic interaction with gangliosides on the cancer cell surface [24]. Buforin IIb, however, is also cytotoxic to normal cells at high concentrations. Therefore, reducing this cytotoxicity is critical if buforin IIb is to be used for drug delivery. It has been reported by many researchers that hemolytic activity and cytotoxicity of $\alpha$ helical peptides are closely correlated with their helicity; stronger helicity usually means the more complete non-polar face of an $\alpha$ helical peptide, which is correlated with its higher apparent hydrophobicity when interacting with cell biomembrane, subsequently contributing to cell membrane lysis [31-33]. Therefore, we stepwisely reduced the helicity of buforin IIb to minimize hemolytic activity and cytotoxic effect of buforin IIb on normal cells while maintaining its cancer cell specificity. The stepwise elimination of the C-terminal RLLR repeats of buforin IIb results in cancer cell specific peptides with reduced cytotoxicity, BR 1 and BR2.

Unlike BR1, BR2 transduced across the plasma membrane of various cancer cells and accumulated in the nucleus and cytoplasm within $30 \mathrm{~min}$. We confirmed the autonomous translocation of BR2 into the cytoplasm with comparable efficiency in all cancer cell types investigated. BR2 penetrated cancer cell membranes more efficiently than the Tat peptide and in a concentrationdependent manner. Moreover, BR1 and BR2 did not show hemolytic activity even at $200 \mu \mathrm{M}$, whereas more than $30 \%$ hemolysis was induced by $200 \mu \mathrm{M}$ BR3. Among the peptides tested, BR2 exhibited an efficient penetration into cancer cells without cytotoxicity to normal cells, whereas BRl displayed a weak cell-penetrating ability and cytotoxicity. From these observations, we can conclude that the number of RLLR repeats at $\mathrm{C}$ terminus affects the cell-penetrating ability and cytotoxicity of peptides. Two RLLR repeats are required for the efficient translocation of buforin-derivatives into cells; however, more than 3 repeats can cause gradual cell damage like that induced by buforin IIb.

Furthermore, we observed a considerable difference between the penetration of BR2 and Tat into normal cells. BR2 showed about 4-fold higher transduction efficiency into cancer cells versus normal cells whereas Tat showed similar penetration efficiency regardless of cell type. Possible reasons for why BR2 displays cancer cell specificity include distinctive features of the cancer cell membrane, such as different membrane composition, altered fluidity, more negative surface charges, higher transmembrane potential and an increased level of acidic components on the surface [34,35]. It is also known that a cancer cell membrane typically contains a net negative charge due to a high expression of anionic molecules such as phosphatidyl serine (PS) and Oglycosylated mucins on the outer membrane leaflet [36]. To identify factors associated with cancer cell specificity of BR2 and analyze the cellular uptake mechanism of BR2, a mechanistic study was performed in HeLa cells, the representative cancer cell line. When we added negatively charged cellular membrane components, such as ganglioside or sialic acid, BR2 uptake was partially inhibited, indicating that exogenous gangliosides and 

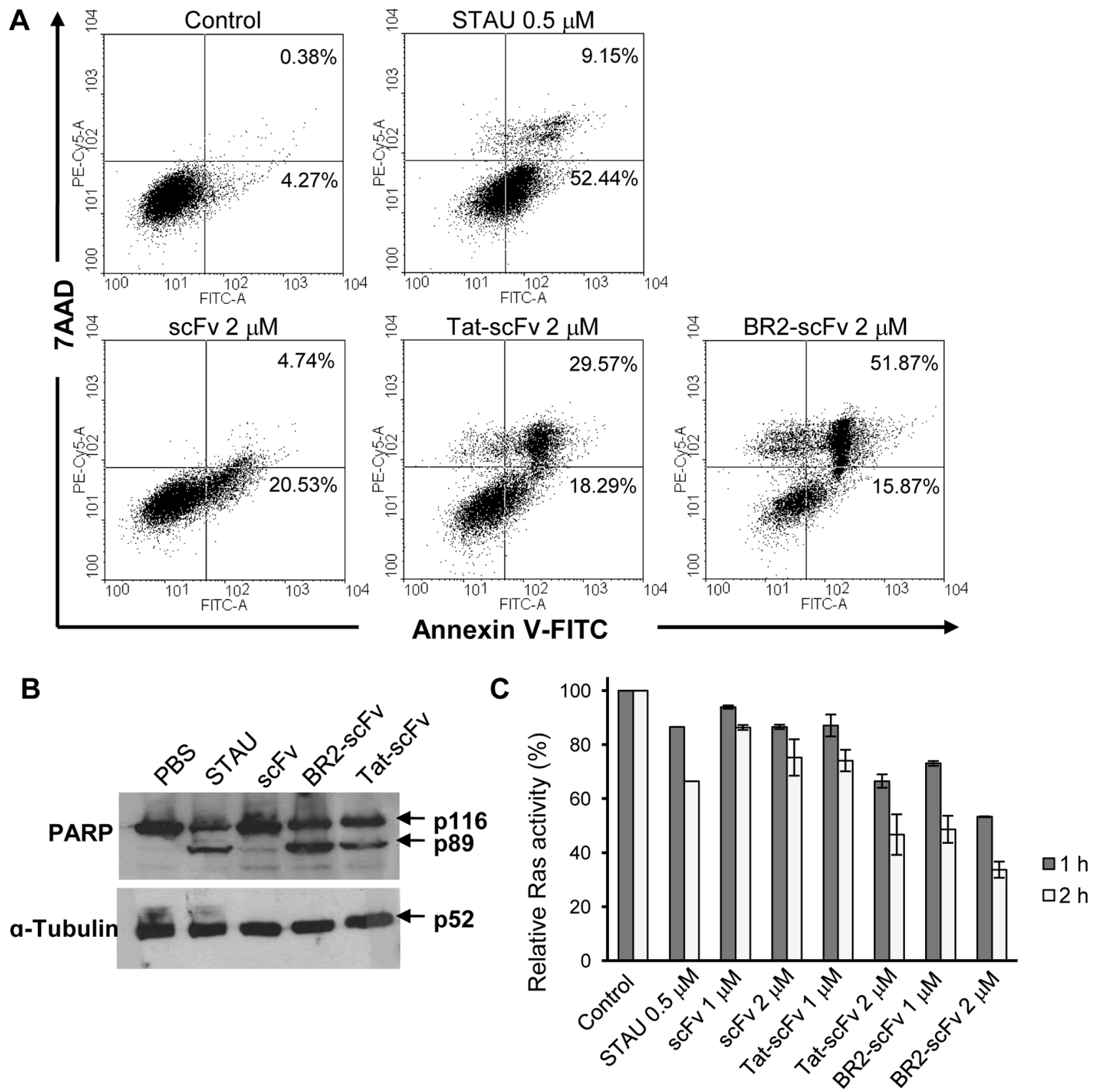

Figure 5. The BR2-anti-Ras SCFv fusion protein promotes apoptosis by blocking Ras signaling in Ras-mutated HCT116 cells. (A) HCT116 cells were treated with anti-Ras scFv, Tat- or BR2-scFv fusion protein (each, $2 \mu \mathrm{M})$ or staurosporine $(0.5 \mu \mathrm{M})$ for $24 \mathrm{~h}$. Cells were stained with Annexin V-FITC and 7AAD to allow detection of apoptotic cell fractions by flow cytometry. The lower left quadrant contains the live cell (double negative) population; the lower right contains the apoptotic (annexin V+/7AAD-) population; the upper right contains the late apoptotic/necrotic (annexin $\mathrm{V}+/ 7 \mathrm{AAD}+$ ) population; and the upper left contains the pre-necrotic (annexin $\mathrm{V}-/ 7 \mathrm{AAD}+$ ) population. The numbers on the top of the quadrants indicate the percentage of apoptotic and late apoptotic/necrotic cells counted from dot plots taken from one representative experiment, performed in triplicate. (B) $24 \mathrm{~h}$ after PBS, anti-Ras scFv, Tat- or BR2-scFv fusion protein (each, $2 \mu \mathrm{M}$ ) or staurosporine $(0.5 \mu \mathrm{M})$ treatment, HCT116 cell extracts were subjected to Western blot analysis with anti-PARP or anti- $\alpha$-tubulin antibodies. The molecular sizes of the proteins are indicated with arrows at the right. $\alpha$-tubulin is shown as a control. (C) Ras activation assay. Changes in Ras activity level in HCT116 cells treated with anti-Ras scFv and BR2- and Tat-scFv fusion proteins (each, 1 and $2 \mu \mathrm{M}$ ) were determined by an ELISA-based activity assay; results are expressed as relative Ras activity (\%).

doi:10.1371/journal.pone.0066084.g005

sialic acids act as antagonists of the same molecules that bind BR2 and thereby hamper this binding. Depleting gangliosides with PPMP also decreased BR2 uptake. However, heparin, another negatively charged component, has almost no effect on BR2 binding to cancer cells. Prior to endocytosis, positively charged
BR2 specifically interacts with negatively charged gangliosides on the cancer cell plasma membrane. In contrast, the high content of zwitterionic phosphatidylcholine in the outer membrane leaflet of normal cells confers an overall neutral charge to these cells, resulting in a reduced capacity for electrostatic interactions with 
BR2. This further decreases cell penetration of BR2 in normal cells.

CPPs are known to be internalized into cells by two different endocytic mechanisms [37], clathrin-dependent and clathrinindependent endocytosis [38-40]. Among several clathrin-independent pathways, lipid raft-mediated macropinocytosis, which gives rise to larger vesicles that do not necessarily fuse with early endosomes [41], is attributed to the internalization of BR2, as confirmed by the experiment using specific endocytosis inhibitors, such as amiloride, methyl- $\beta$-cyclodextrin, and nocodazole (Fig. 3B). Furthermore, the LysoTracker probes, which were used to track acidic organelle like lysosomes, revealed that most of internalized BR2s are present in the cytoplasm, but not in the lysosome, escaping lysosomal degradation. These results clearly show that BR2 can be an effective and long-lasting drug delivery vehicle.

Given the need for efficient therapeutic protein delivery systems, we investigated the possibility of using BR2 for delivering an anticancer therapeutic protein by fusing it with anti-p21 Ras Y13$259 \mathrm{scFv}$. Ras is a small GTP-binding protein that plays a critical role in the regulation of cell proliferation, transformation and differentiation. Over-expression or mutations in the Ras oncogene have been identified in a large number of human tumors $(\sim 30 \%)$ and therefore constitute a primary target for cancer treatment [42]. It was reported that microinjection of the neutralizing antiRas monoclonal antibody Y13-259 into Ras-transformed rodent fibroblasts induces transient phenotypic reversion the cells in vitro and inhibits all biological responses that require Ras proteins $[43,44]$. Moreover, intracellular expression of $\mathrm{scFv}$, a fragment derived from antibody Y13-259, specifically promoted apoptosis in human cancer cells in vitro and led to tumor regression in a colon carcinoma tumor model in vivo [45]. Thus, in this study, we made recombinant proteins in which BR2 and Tat peptides were fused with anti-Ras scFv. These peptide-scFv constructs were efficiently internalized into K-ras mutated colon cancer HCT116 cells within $2 \mathrm{~h}$. BR2 delivered anti-Ras $\mathrm{scFv}_{\mathrm{V}}$ into the cells $32.6 \%$ more efficiently than Tat did, whereas peptide-unconjugated $\mathrm{scFv}_{\mathrm{V}}$ was not detectable in the intracellular region.

BR2- and Tat-anti Ras scFv fusion proteins clearly exerted strong anti-proliferative activity in exponentially growing Rasmutated cancer cells by inducing apoptosis, whereas BR2, Tat or unconjugated $\mathrm{scF}_{\mathrm{V}}$ did not show any detectable inhibitions at the same concentrations. It seems that BR2 and Tat contribute to the enhancement of intracellular delivery of conjugated scFvs without causing the cytotoxicity against HCT116. The better internalization efficiency of BR2-fused $\mathrm{scFv}$ in cancer cells may be the basis for the higher anticancer activity of this fusion protein as compared with Tat-scFv. Furthermore, inactivation of GTP-Ras proteins inside tumor cells might be mediated via neutralization by specific binding between Ras and $\mathrm{BR} 2-\mathrm{scF}$ v fusion proteins. Our results clearly suggest that BR2 promotes delivery and proper localization of fused $\mathrm{scFv}$ antibody fragments to their target antigen, the Ras protein. These results imply that after peptide$\mathrm{scF}_{\mathrm{V}}$ fusion proteins penetrated the cell membranes, they specifically bound and neutralized the target mutant GTP-Ras proteins. All of these findings suggest that biologically active antiRas $\mathrm{scF}_{\mathrm{V}}$ can be efficiently introduced into target cancer cells by BR2.

In conclusion, we have found a novel CPP, BR2, which specifically penetrates cancer cells without causing cytotoxicity to normal cells. BR2 can be used to transport therapeutic proteins efficiently into target cells by covalent conjugation with the cargoes, which retain bioactivity. Although further studies are needed to assess the utility of using BR2 in vivo for delivering other kinds of therapeutics into target cancer cells as well as the feasibility of simple conjugations of BR2 to therapeutics for practical cancer therapy, the cancer-specific cell-penetrating peptide BR2 will provide valuable tools for the efficient cancer therapies.

\section{Supporting Information}

Figure S1 Gancer cell specific penetration of BR2. Specific penetration into cancer cells of FITC-labeled Tat and BR2 were examined in the presence of both cancer and normal cells by confocal laser microscopy. HeLa and BJ fibroblast cells were seeded and co-cultured in the same well of a 6-well plate 1 day prior to the experiment to reach $70 \%$ confluence. Cells were incubated with FITC-labeled Tat or BR2 $(5 \mu \mathrm{M})$ for $30 \mathrm{~min}$ at $37^{\circ} \mathrm{C}$ and washed three times with phosphate buffered saline (PBS). Nuclei were stained with Hoechst 33342 (blue). Peptide internalization was then analyzed using a confocal laser microscope. HeLa cells and BJ fibroblast cells were indicated with red arrows and white arrows, respectively.

(TIF)

Figure S2 Efficient protein transduction mediated by BR2. (A) Schematic representation of peptide-EGFP cDNA constructs. DNA encoding peptides (Tat, BR1 or BR2) and EGFP were fused as described in Supplementary Materials and Methods in Information $\mathrm{S} 1$ and cloned into the $B g / \mathrm{II}$ and $\mathcal{N} d e \mathrm{I}$ sites of pET16b. The $B g I I$ and $\mathcal{N} d e \mathrm{I}$ restriction sites and factor $\mathrm{Xa}$ cleavage site are indicated. (B,C) Cellular uptake of peptide-EGFP fusion proteins was analyzed by confocal laser microscopy and flow cytometry. Purified EGFP or peptide-EGFP fusion proteins $(10 \mu \mathrm{M})$ were incubated with HeLa cells at $37^{\circ} \mathrm{C}$ for $2 \mathrm{~h}$.

(TIF)

Figure S3 Intracellular localization of peptides and anti-Ras ScFv fusion proteins using immunocytochemistry. Intracellular localization of fusion proteins was analyzed in HCT116 cells by immunocytochemistry. HCT116 cells were incubated with $\mathrm{scFv}_{\mathrm{v}}$, Tat-scFv or BR2-scFv fusion protein (each, $2 \mu \mathrm{M})$ for $2 \mathrm{~h}$ at $37^{\circ} \mathrm{C}$. Cells were washed with PBS, fixed and permeabilized. FITC-conjugated anti-His antibody was used to detect intracellular localization of $\mathrm{scFv}$, Tat-scFv and $\mathrm{BR} 2-\mathrm{scFv}$. Nuclei were stained with DAPI (blue). Intracellular localization of fusion proteins was then analyzed by confocal laser microscope. (TIF)

Figure S4 Gytotoxic effect of BR2 and Tat against HCT116 cells. HCT 116 cells were treated with PBS, BR2 or Tat $(0,1,2$ and $5 \mu \mathrm{M})$ and incubated for $24 \mathrm{~h}$. Cell viability was measured by MTT assay. Data represent the mean \pm s.d. of three independent experiments.

(TIF)

Information S1.

(DOCX)

\section{Acknowledgments}

We would like to thank Prof. Ju Hyun Cho and Dr. Jin Huh for thoughtful discussions, and Dr. Heather McDonald for valuable editorial assistance.

\section{Author Contributions}

Conceived and designed the experiments: KJL BHS SGK. Performed the experiments: KJL. Analyzed the data: KJL JRS BHS. Contributed reagents/materials/analysis tools: KJL JRS BHS YWL DJK KSY SCK. Wrote the paper: KJL BHS SCK. 


\section{References}

1. Martin I, Teixido M, Giralt E (2010) Building cell selectivity into CPP-mediated strategies. Pharmaceuticals 3: 1456-1490.

2. Torchilin V (2008) Intracellular delivery of protein and peptide therapeutics. Drug Discovery Today: Technologies 5: 95-103.

3. Pujals S, Giralt E (2008) Proline-rich, amphipathic cell-penetrating peptides. Adv Drug Deliv Rev 60: 473-484.

4. Elmquist A, Lindgren M, Bartfai T, Langel U (2001) VE-cadherin-derived cellpenetrating peptide, pVEC, with carrier functions. Exp Cell Res 269: 237-244.

5. Vives E, Brodin P, Lebleu B (1997) A truncated HIV-1 Tat protein basic domain rapidly translocates through the plasma membrane and accumulates in the cell nucleus. J Biol Chem 272: 16010-16017.

6. Manish G, Vimukta S (2011) Targeted drug delivery system: a review. Res J ChemSci 1: 135-138.

7. Wang B, Siahaan TJ, Soltero R (2005) Drug Delivery: Principles and Applications.

8. Kamada H, Okamoto T, Kawamura M, Shibata H, Abe Y, et al. (2007) Creation of novel cell-penetrating peptides for intracellular drug delivery using systematic phage display technology originated from Tat transduction domain. Biol Pharm Bull 30: 218-223.

9. Zorko M, Langel U (2005) Cell-penetrating peptides: mechanism and kinetics of cargo delivery. Advanced Drug Delivery Reviews 57: 529-545.

10. Fawell S, Seery J, Daikh Y, Moore G, Chen LL, et al. (1994) Tat-mediated delivery of heterologous proteins into cells. Proc Natl Acad Sci U S A 91: 664 668.

11. Johnson LN, Cashman SM, Kumar-Singh R (2008) Cell-penetrating peptide for enhanced delivery of nucleic acids and drugs to ocular tissues including retina and cornea. Mol Ther 16: 107-114.

12. Chiu YL, Ali A, Chu CY, Cao H, Rana TM (2004) Visualizing a correlation between siRNA localization, cellular uptake, and RNAi in living cells. Chem Biol 11: 1165-1175.

13. Turner JJ, Ivanova GD, Verbeure B, Williams D, Arzumanov AA, et al. (2005) Cell-penetrating peptide conjugates of peptide nucleic acids (PNA) as inhibitors of HIV-1 Tat-dependent trans-activation in cells. Nucleic Acids Res 33: 68376849.

14. Rothbard JB, Garlington S, Lin Q Kirschberg T, Kreider E, et al. (2000) Conjugation of arginine oligomers to cyclosporin A facilitates topical delivery and inhibition of inflammation. Nat Med 6: 1253-1257.

15. Yukawa H, Kagami Y, Watanabe M, Oishi K, Mivamoto Y, et al. (2010) Quantum dots labeling using octa-arginine peptides for imaging of adipose tissue-derived stem cells. Biomaterials 31: 4094 4103.

16. Lewin M, Carlesso N, Tung CH, Tang XW, Cory D, et al. (2000) Tat peptidederivatized magnetic nanoparticles allow in vivo tracking and recovery of progenitor cells. Nat Biotechnol 18: 410-414.

17. Heitz F, Morris MC, Divita G (2009) Twenty years of cell-penetrating peptides: from molecular mechanisms to therapeutics. Br J Pharmacol 157: 195-206.

18. Trabulo S, Cardoso A, Mano M, Pedroso de Lima M (2010) Cell-penetrating peptides - Mechanisms of cellular uptake and generation of delivery systems. Pharmaceuticals 3: 961-993.

19. Hoyer J, Neundorf I (2012) Peptide vectors for the nonviral delivery of nucleic acids. Acc Chem Res 45: 1048-1056.

20. Mussbach F, Franke M, Zoch A, Schaefer B, Reissmann S (2011) Transduction of peptides and proteins into live cells by cell penetrating peptides. J Cell Biochem 112: 3824-3833.

21. Kersemans V, Cornelissen B (2010) Targeting the tumour: Cell penetrating peptides for molecular imaging and radiotherapy. Pharmaceuticals 3: 600-620.

22. Geisler I, Chmielewski J (2009) Cationic amphiphilic polyproline helices: sidechain variations and cell-specific internalization. Chem Biol Drug Des 73: 3945.

23. Martin I, Teixido M, Giralt E (2010) Building cell selectivity into CPP-mediated strategies. Pharmaceuticals 3: 1456-1490.

24. Lee HS, Park CB, Kim JM, Jang SA, Park IY, et al. (2008) Mechanism of anticancer activity of buforin IIb, a histone H2A-derived peptide. Cancer Lett 271: $47-55$.
25. Cho JH, Sung BH, Kim SC (2009) Buforins: histone H2A-derived antimicrobial peptides from toad stomach. Biochim Biophys Acta 1788: 1564-1569.

26. Lundberg M, Johansson M (2002) Positively charged DNA-binding proteins cause apparent cell membrane translocation. Biochem Biophys Res Commun 291: $367-371$

27. Richard JP, Melikov K, Vives E, Ramos C, Verbeure B, et al. (2003) Cellpenetrating peptides. A reevaluation of the mechanism of cellular uptake. J Biol Chem 278: 585-590.

28. Aboudy Y, Mendelson E, Shalit I, Bessalle R, Fridkin M, et al. (1994) Activity of two synthetic amphiphilic peptides and magainin-2 against herpes simplex virus types 1 and 2. Int. J. Peptide Protein Res., 43: 6, 573-582.

29. Crombez L, Aldrian-Herrada G, Konate K, Nouyen ON, McMaster GK, et al. (2009) A new potent secondary amphipathic cell-penetrating peptide for siRNA delivery into mammalian cells, Molecular Therapy, 17, 95-103.

30. Bradford MM (1976) A rapid and sensitive method for the quantitation of microgram quantities of protein utilizing the principle of protein-dye binding. Anal Biochem 72: 248-254.

31. Shin SY, Lee SH, Yang ST, Park EJ, Lee DG, et al. (2001) Antibacterial, antitumor and hemolytic activities of alpha-helical antibiotic peptide, P18 and its analogs. J Pept Res 58: 504-514.

32. Chen Y, Mant CT, Farmer SW, Hancock RE, Vasil ML, et al. (2005) Rational design of alpha-helical antimicrobial peptides with enhanced activities and specificity/therapeutic index. J Biol Chem 280: 12316-12329.

33. Huang YB, He LY, Jiang HY, Chen YX (2012) Role of helicity on the anticancer mechanism of action of cationic-helical peptides. Int J Mol Sci 13: 6849-6862.

34. Leuschner C, Hansel W (2004) Membrane disrupting lytic peptides for cancer treatments. Curr Pharm Des 10: 2299-2310.

35. Papo N, Shai Y (2003) New lytic peptides based on the D,L-amphipathic helix motif preferentially kill tumor cells compared to normal cells. Biochemistry 42 : 9346-9354.

36. Cappelli G, Paladini S, D'Agata A (1999) Tumor markers in the diagnosis of pancreatic cancer. Tumori 85: S19-21.

37. Madani F, Lindberg S, Langel U, Futaki S, Graslund A (2011) Mechanisms of cellular uptake of cell-penetrating peptides. J Biophys 2011: 414729.

38. Doherty GJ, McMahon HT (2009) Mechanisms of endocytosis. Annu Rev Biochem 78: 857-902.

39. Cawthorn TR, Amir E, Broom R, Freedman O, Gianfelice D, et al. (2009) Mechanisms and pathways of bone metastasis: challenges and pitfalls of performing molecular research on patient samples. Clin Exp Metastasis 26: 935943.

40. Harvey TM, Emmanuel B (2011) Molecular mechanism and physiological functions of clathrin-mediated endocytosis. Nature Reviews Molecular Cell biology 12: 517-533.

41. Kirsten S, Sascha P, Tore S, Bo van D (2011) Clathrin-independent endocytosis: mechanisms and function. Current Opinion in Cell Biology 23: 413-420.

42. Tanaka T, Rabbitts TH (2003) Intrabodies based on intracellular capture frameworks that bind the RAS protein with high affinity and impair oncogenic tramsformation. EMBO J 22: 1025-1035.

43. Deshpande AK, Kung HF (1987) Insulin induction of Xenopus laevis oocyte maturation is inhibited by monoclonal antibody against p21 ras proteins. Mol Cell Biol 7: 1285-1288.

44. Fox PL, Sa G, Dobrowolski SF, Stacey DW (1994) The regulation of endothelial cell motility by p21 ras. Oncogene 9: 3519-3526.

45. Cochet O, Keniosberg M, Delumeau I, Virone-Oddos A, Multon MC, et al. (1998) Intracellular expression of an antibody fragment-neutralizing p21 ras promotes tumor regression. Cancer Res 58: 1170-1176.

46. Jeyapaul J, Reddy MR, Khan SA (1990) Activity of synthetic tat peptides in human immunodeficiency virus type 1 long terminal repeat-promoted transcription in a cell-free system. Proc Natl Acad Sci U S A 87: 7030-7034.

47. Park CB, Yi KS, Matsuzaki K, Kim MS, Kim SC (2000) Structure-activity analysis of buforin II, a histone $\mathrm{H} 2 \mathrm{~A}$-derived antimicrobial peptide: the proline hinge is responsible for the cell-penetrating ability of buforin II. Proc Natl Acad Sci U S A 97: 8245-8250. 